Kontrola dopinga kao mera prevencije:

Iskustvo Antidoping agencije republike Srbije

\title{
Doping Prevention: Experience of Antidoping Agency of Serbia
}

\author{
Nenad Dikićl
}

${ }^{1}$ Antidoping agencija Republike Srbije

Kontakt: nenad.dikic@gmail.com

\section{Sažetak}

Potpisivanjem Kopenhagenške deklaracije o dopingu u sportu u decembru 2003. godine stvorena je osnova za donošenje Zakona o sprečavanju dopinga u sportu. Skupština Republike Srbije je prvi put usvojila ovaj zakon 2005. godine, na osnovu koga je osnovana Antidoping agencija Republike Srbije (ADAS). S obzirom na izmene koje pretrpeo Svetski antidoping kodeks, Skupština Republike Srbije je u oktobru 2014. godine donela novi Zakon o sprečavanju dopinga u sportu. Iza svih ovih zakonodavnih i državnih aktivnosti je, međutim, stajalo višegodišnje iskustvo i znanje članova Udruženja za medicinu sporta Srbije (UMSS), koji su sprovodili doping kontrole i kada nije postojala zvanična agencija i tako započeli jednu novu aktivnost koju do tada lekari nisu radili.

Antidoping agencija Republike Srbije je, osim toga, jedna od retkih antidoping organizacija na svetu u kojima kao doping kontrolori rade samo ljudi zdravstvene struke. Tako su postavljeni najviši standardi, koje imaju i Međunarodna košarkaška federacija (FIBA), Udruženje evropskih fudbalskih asocijacija (UEFA), Međunarodna federacija fudbalskih asocijacija (FIFA) i ne više od $20 \%$ evropskih nacionalnih antidoping organizacija (NADO). Na ovo smo jako ponosni jer smo stvorili instituciju koja predstavlja baštinu za dobrobit budućih generacija lekara.

$\mathrm{U}$ trenutku kada je osnivana Antidoping agencija Republike Srbije smatralo se da u Srbiji ne postoji problem dopinga i da se srpski sportisti ne dopinguju. Broj otkrivenih slučajeva pozitivnih na doping, međutim, jasno govori u prilog činjenici da taj problem postoji, ali i da se tokom godina broj sportista pozitivnih na doping smanjivao zahvaljujući, pre svega, upornom radu na edukaciji ne samo sportista već i ostalih sportskih radnika.

U periodu od osnivanja do 1. januara 2016. godine Antidoping agencija Republike Srbije sprovela je ukupno 5974 doping kontrola, a 62 sportista je bilo pozitivno na doping na preko 70 različitih zabranjenih supstanci.

Ključne reči: doping kontrola, antidoping agencija, lista zabranjenih supstanci

\begin{abstract}
By signing the Copenhagen Declaration on Doping in Sport, in December 2003, the basis was created for the adoption of the Law on prevention of doping in sports. The Parliament of Serbia has adopted this law firstly in 2005, on the basis of which was established Antidoping Agency of Serbia (ADAS). Due to changes, which are done on the World Antidoping Code, the Parliament of Serbia has adopted a new Law on the Prevention of doping in sport in 2014. Behind all these legislative and governmental activity, however, there is a long experience and knowledge of members of the Sports Medicine Association of Serbia, who conducted the doping control when there was no official agency and started a new activity that, until then, doctors did not practice.
\end{abstract}

Not only that, ADAS is one of the few antidoping organization in the world where only the people in health profession are working as a doping control officers. ADAS set the highest standards that have the most important international federations (FIBA, UEFA, FIFA etc.) and not more than $20 \%$ of national antidoping organization. For this we are very proud, because we have created an institution that represents the heritage for the future generations of medical doctors.

By the time ADAS has been established, it was considered there is no problem of doping in Serbia. However, the number of doping positive cases clearly supports the fact that the problem exists. Over the years, the number of athletes who are tested positive, have decreased, primarily due to hard work on education, not only of the athletes, but also of the other sports officials.

From the period of establishment until January 1, 2016, ADAS has completed a total of 5974 doping controls and 62 athletes have been tested positive for doping on over 70 different banned substances.

Key words: Doping controls, Antidoping agency, Prohibited list 
Potpisivanjem Kopenhagenške deklaracije o dopingu u sportu u decembru 2003. godine stvorena je osnova za donošenje Zakona o sprečavanju dopinga u sportu. Skupština Republike Srbije je ovaj zakon, kojim je osnovana Antidoping agencija Republike Srbije (ADAS), usvojila 14. novembra 2005. godine, a nepunih mesec dana kasnije - 12. decembra 2005. konstituisan je Upravni odbor ADAS i započet rad na uspostavljanju sistema borbe protiv dopinga u Srbiji u skladu sa međunarodnim normama i standardima.

Srbija je 2009. godine ratifikovala Međunarodnu konvenciju protiv dopinga u sportu pod okriljem UNESCO i time preuzela obavezu da preduzme „dalje i jače akcije usmerene ka eliminaciji dopinga u sportu". Svetski antidoping kodeks iz 2009. je u procesu revizije pod rukovodstvom Svetske antidoping agencije (WADA) pretrpeo značajne izmene tako da je 1. januara 2015. godine na snagu stupio novi svetski antidoping kodeks. S obzirom na značajne izmene koje je ovaj novi svetski antidoping kodeks doneo, a i na obavezu koju smo kao zemlja preuzeli potpisivanjem Međunarodne konvencije, bila je neophodna i izmena Zakona o sprečavanju dopinga u sportu. Tako je u oktobru 2014. godine donet novi Zakon o sprečavanju dopinga u sportu.

Treba reći da su svi ovi napori prvenstveno urađeni da bi se omogućio nesmetan razvoj našeg sporta jer je jedna od mogućih sankcija za nepridržavanje normi međunarodnih konvencija i nepostojanje zakona koji regulišu borbu protiv dopinga u sportu i zabrana učestvovanja sportista na Olimpijadi i međunadnim takmičenjima.

Iza svih ovih zakonodavnih i državnih aktivnosti je, međutim, stajalo višegodišnje iskustvo i znanje članova Udruženja za medicinu sporta Srbije (UMSS), koji su sprovodili doping kontrole i kada nije postojala zvanična agencija. Može se slobodno reći da je idejni tvorac Antidoping agencije Republike Srbije dr Nenad Dikić, koji je, kao generalni sekretar UMSS, okupio mlade doktore i organizovao ih tako da su mogli da počnu sa jednom novom aktivnošću koju do tada lekari nisu radili. I ne samo to, ADAS je jedna od retkih antidoping organizacija (ADO) u kojima samo ljudi zdravstvene struke rade kao doping kontrolori. Tako su postavljeni najviši standardi koji imaju Međunarodna košarkaška federacija (FIBA), Udruženje evropskih fudbalskih asocijacija (UEFA), Međunarodna federacija fudbalskih asocijacija (FIFA) i ne više od 20\% evropskih nacionalnih antidoping organizacija (NADO). I danas u redovima ADAS ima oko 40 lekara i nekoliko farmaceuta koji i bukvalno predstavljaju elitu evropskih doktora angažovanih u borbi protiv dopinga u sportu. $\mathrm{Na}$ ovo smo jako ponosni jer smo stvorili instituciju koja predstavlja baštinu za dobrobit budućih generacija lekara.

U trenutku kada je osnivana Antidoping agencija Republike Srbije smatralo se da u Srbiji ne postoji problem dopinga i da se srpski sportisti ne dopinguju. Broj otkrivenih slučajeva pozitivnih na doping, međutim, jasno govori u prilog činjenici da taj problem postoji, ali i da se tokom godina broj sportista pozitivnih na doping smanjivao zahvaljujući, pre svega, upornom radu na edukaciji ne samo sportista već i ostalih sportskih radnika.

U periodu od osnivanja do 1. januara 2016. godine Antidoping agencija Republike Srbije sprovela je ukupno 5974 doping kontrola, a 62 sportista je bilo pozitivno na doping na preko 70 različitih zabranjenih supstanci.

Sportisti pozitivni na doping su bili iz 22 različita od ukupno testirana 83 sporta. Najveći broj pozitivnih na doping bio je u rvanju (7), nakon toga u bodibildingu i rukometu (po 6), u boksu (5), u atletici (4), u košarci (3),

Tabela 1. Doping kontrole u Srbiji 2006-2015.

\begin{tabular}{lccc}
\hline Godina & Ukupno testirani po godinama & Broj sportista pozitivnih na doping & Druge povrede antidoping pravila \\
\hline 2006. & 31 & 1 & 0 \\
2007. & 347 & 0 & 0 \\
2008. & 494 & 8 & 1 \\
2009. & 767 & 3 & 1 \\
2010. & 717 & 20 & 1 \\
2011. & 1021 & 12 & 0 \\
2012. & 605 & 4 & 0 \\
2013. & 537 & 1 & 0 \\
2014. & 725 & 4 & 0 \\
2015. & 703 & 8 & 0 \\
\hline Ukupno & 5947 & 62 & 3 \\
\hline
\end{tabular}




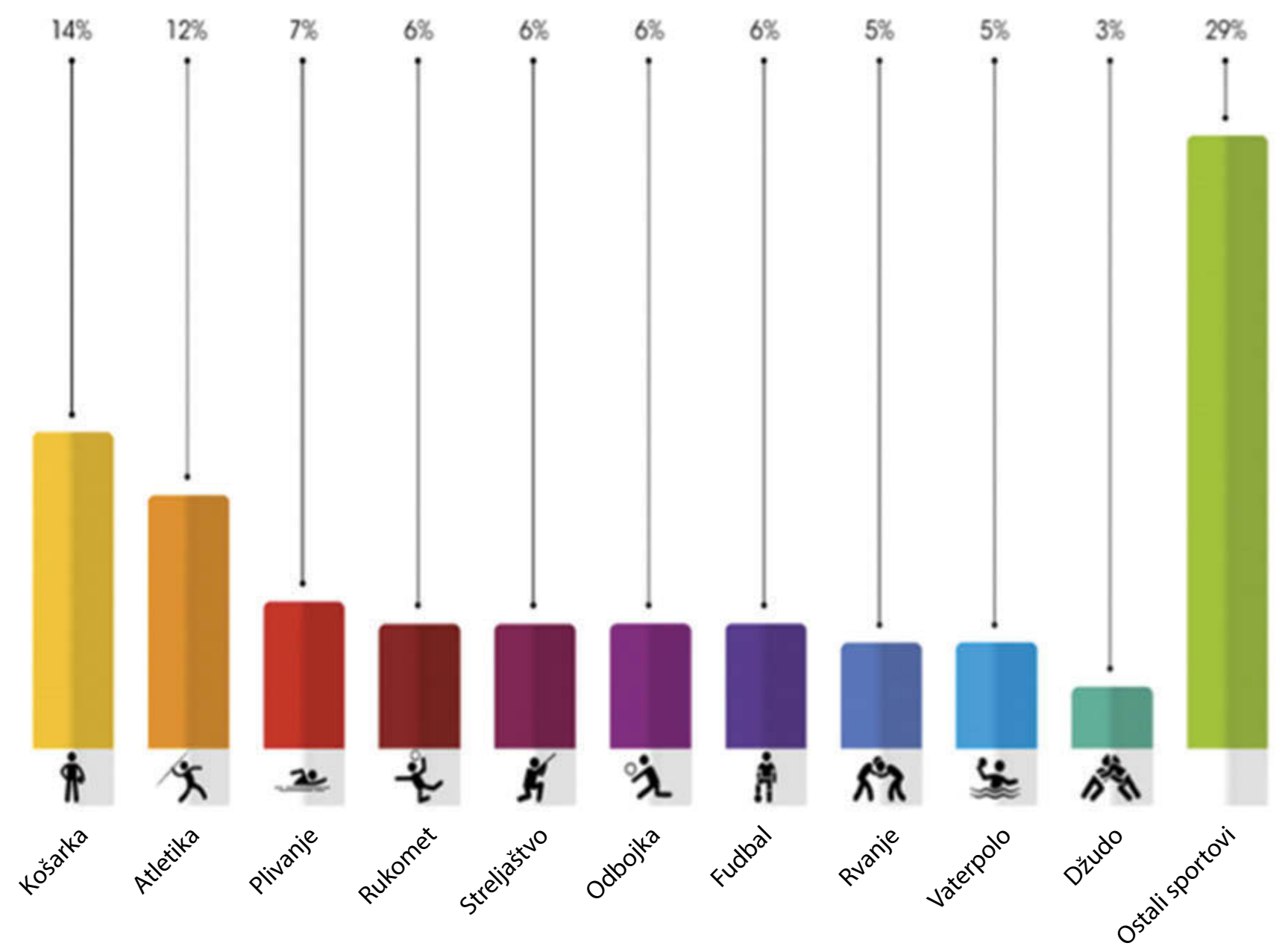

Grafikon 1. Kontrolisani sportisti po sportovima 2006-2015.

zatim u dizanju tegova, ragbiju 13, američkom fudbalu, kik boksu i biciklizmu (po 2), a najmanje u karateu, veslanju, kajakaštvu, tenisu, fudbalu, hokeju na ledu, džudou, streljaštvu, bobu i među džokejima (po 1).

Tokom deset godina postojanja, pored prisustva zabranjene supstance u telesnom uzorku sportiste, imali smo i 3 druge povrede antidoping pravila kao što su ometanje doping kontrole, davanje doping sredstava sportisti i pokušaj korišćenja i posedovanje zabranjenih supstanci. Procentualna raspodela između grupa supstanci na koje su sportisti bili doping pozitivni gotovo se ne razlikuje od one na svetskom nivou. Naime, $48,57 \%$ od svih prisutnih supstanci na koje su sportisti bili doping pozitivni su anabolički steroidi, 18,57\% su kanabinoidi, 15,71\% stimulansi, $14,29 \%$ diuretici i $1,43 \%$ beta blokatori i beta 2 agonisti.

Sve supstance zabranjene u sportu nalaze se na jedinstvenoj listi koja se menja najmanje jednom godišnje i zvanično objavljuje na engleskom jeziku na internet stranici WADA i na srpskom jeziku na internet stranici ADAS. Osnovna podela zabranjenih supstanci je na one koje su uvek zabranjene i na supstance zabranjene samo na takmičenjima. Pored toga, postoje supstance zabranjene samo u pojedinim sportovima.

Antidoping agencija Republike Srbije od početka radi na razvijanju biološkog pasoša, aktivno sprovodeći doping kontrolu krvi pored standardne analize urina, prateći parametre krvi i anaboličkih steroida kod najboljih u sportovima izdržljivosti. Poštujući tehnički dokument za specifične analize, ADAS od 2015. godine redovno analizira stimulatore eritropoeze (ESA), oslobađajuće faktore hormona rasta (GHRF), kao i sam hormon rasta (GH).

Antidoping agencija od 2008. godine sprovodi i doping kontrole konja jer smatramo da zaštita životinja treba da bude važan segment našeg delovanja. U periodu od 2008. do 1. juna 2015. godine sproveli smo 338 doping kontrola konja, a od ukupnog broja testiranih 28 je bilo pozitivno na doping. Kuriozitet kod doping kontrole konja je da se svaka supstanca koja se nađe u njihovom organizmu smatra dopingom, pa smo u tom smislu imali konje pozitivne na na sledeće supstance: fenilbutazon, fluniksin, diklofenak, triamcinolone acetonid, kofein, heptaminol, teofilin, furosemid, deksametazon, ketorolak, oksifenbutazon, salicilnu kiselinu, mentol, lidokain, 3 hidroksilidokain. Kao 


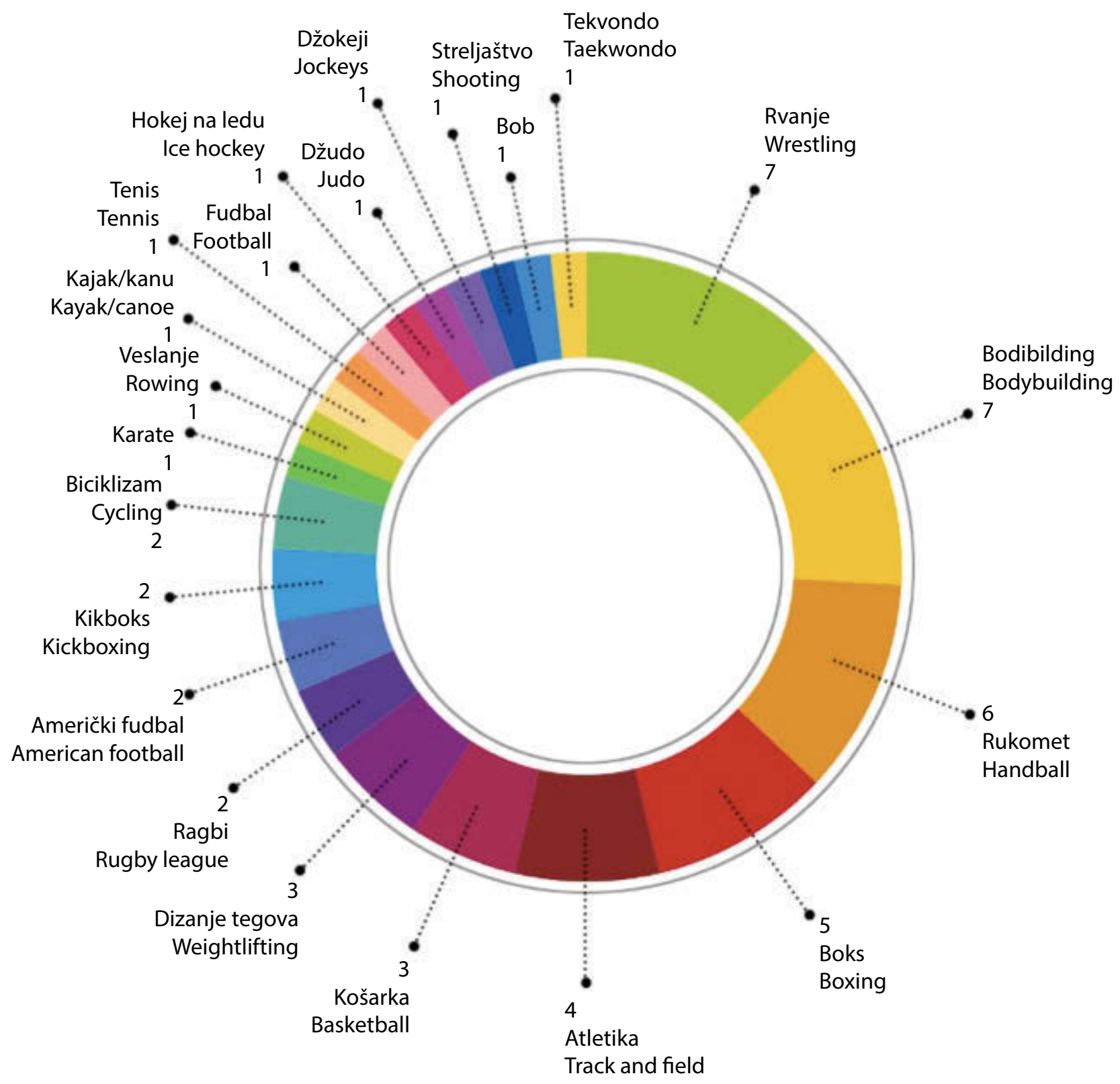

Grafikon 2. Slučajevi pozitivni na doping po sportovima 2006-2015.

i u slučaju kontrole sportista, angažovani su isključivo doktori veterinarske medicine, čime smo zaštitili struku, ali i podigli nivo usluge na najviši nivo.

Napori Antidoping agencije Republike Srbije su očigledno uticali i na shvatanje javnog mnjenja da se sportski rezultat može postići i bez dopinga. Smatrajući da je edukacija jedini pravi put za smanjenje slučajeva pozitivnih na doping u Srbiji, Antidoping agencija Republike Srbije je u prethodnih deset godina održala preko 400 edukativnih sastanaka, od toga 9 antidoping seminara, 4 kongresa o dijetetskim suplementima, 12 Pansport seminara ili u proseku 1 predavanje nedeljno za sve učesnike u sportu i 2 edukacije godišnje za 350 najboljih sportista stipendista Ministarstva omladine i sporta. Od 2015. godine ADAS organizuje Kongres o prevenciji dopinga u sportu.
U okviru svoje izdavačke delatnosti ADAS je pomogao izdavanje knjiga „100 pitanja o dopingu“ i „Praktična sportska ishrana“, priručnika za sportiste „Džepni priručnik o dopingu“, kao i dvojezičnu knjigu „Druga strana medalje/Both sides clean", u kojoj poznati iz sveta sporta i kulture govore o fenomenu dopinga. Samo u 2015. godini ADAS je učestvovao u izdanju tri knjige: „Sportski kuvar“, „Intolerancija na hranu u sportu“ i „Probiotici u sportu“, koje se indirektno tiču dopinga i omogućio da ih najbolji srpski sportisti dobiju na poklon.

Velika pažnja je posvećena i etici koja predstavlja jedan od tri stuba na kojima počiva borba protiv dopinga u sportu, pa je tako dr Nenad Dikić objavio dva rada: „Sports physicians, ethics and antidoping governance: between assistance and negligence " $\mathrm{i}$ "On the Efficacy of WADAs 


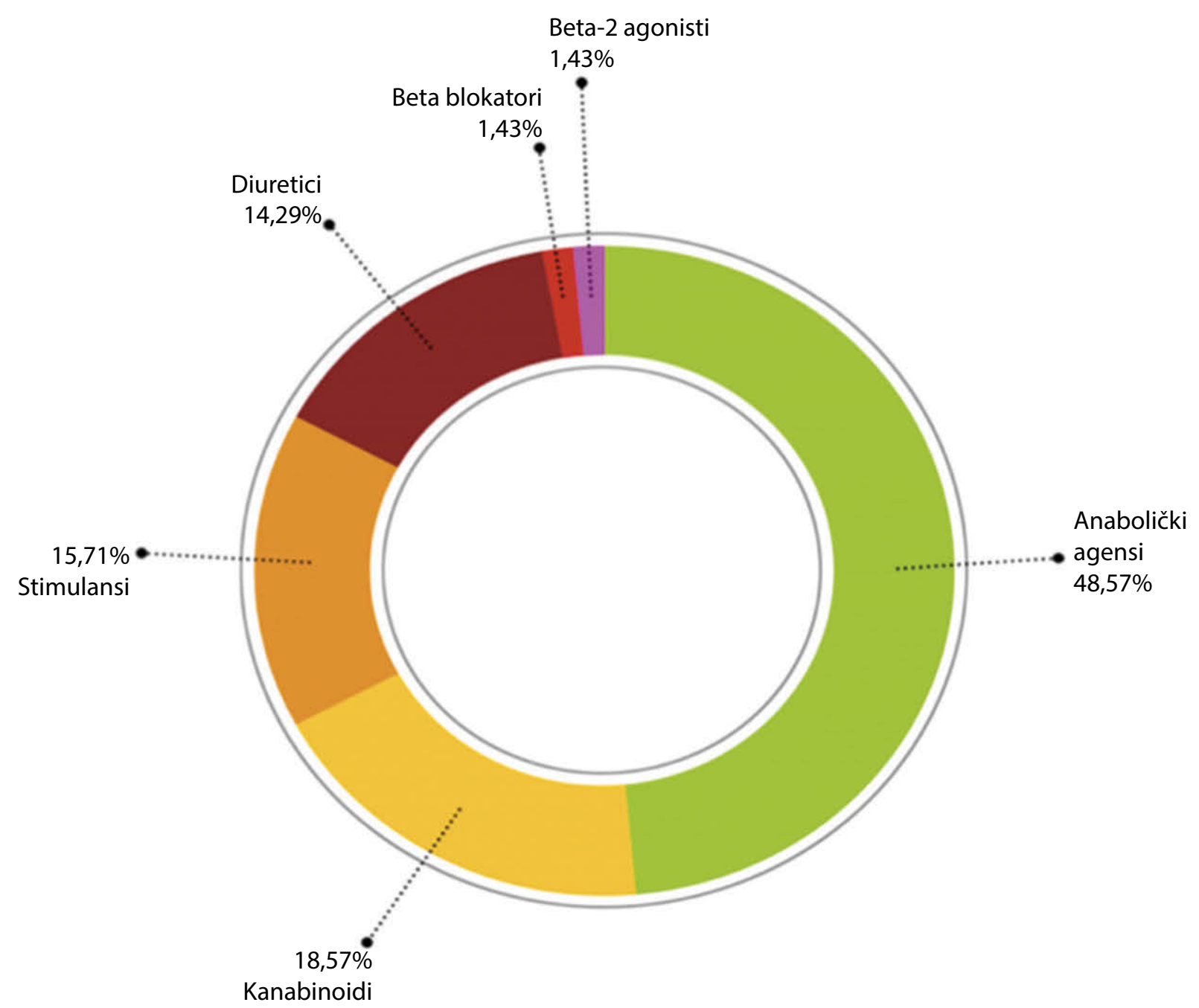

Grafikon 3. Zastupljenost nedozvoljenih supstanci 2006-2015.

Whereabouts Policy: Between Filing Failures and Missed Upravo zahvaljujući kontinuiranoj edukaciji uspeli smo Tests" i napisao poglavlje u Springerovoj enciklopediji o da kroz godine unazad smanjimo broj sportista pozitivetičkim dilemama dopinga. nih na doping i ukažemo im ne samo na etičke probleme

Tabela 2. Lista zabranjenih supstanci i metoda

\begin{tabular}{ll}
\hline Supstance i metode uvek zabranjene (na takmičenju i van takmičenja) & Supstance i metode zabranjene na takmičenju \\
\hline S0. Lekovi u kliničkim ispitivanjima & S6. Stimulansi \\
S1. Anabolički steroidi & S7. Narkotici \\
S2. Peptidni hormoni, faktori rasta i srodne supstance & S8. Kanabinoidi \\
S3. Beta 2 agonisti & S9.glukokortikosteroidi \\
S4. Hormoni i metabolički modulatori & Supstance zabranjene u određenim sportovima \\
S5. Diuretici i drugi maskirajući agensi & P1. Alkohol \\
Zabranjene metode & P2. Beta blokatori \\
M1. Poboljšanje transporta kiseonika & \\
M2. Hemijske i fizičke manipulacije & \\
M3. Genski doping & \\
\hline
\end{tabular}


Tabela 3. Doping kontrola konja

\begin{tabular}{lccc}
\hline Godina & Broj doping kontrola & Broj konja pozitivnih na doping & Procenta konja pozitivnih na doping \\
\hline 2008. & 49 & $4+1$ & $10,2 \%$ \\
2009. & 27 & 2 & $7,4 \%$ \\
2010. & 60 & $3+1$ & $6,6 \%$ \\
2011. & 68 & 6 & $2,8 \%$ \\
2012. & 35 & 1 & $11,11 \%$ \\
2013. & 36 & 4 & $10,71 \%$ \\
2014. & 56 & 6 & $5,17 \%$ \\
2015. & 58 & 3 & $7,96 \%$ \\
\hline Ukupno & 389 & 31 & 0 \\
\hline
\end{tabular}

već i na, što je mnogo značajnije, štetne posledice po zdravlje koje uzimanje doping supstanci ima. Dok smo u 2010. godini imali $4 \%$ sportista pozitivnih na doping u odnosu na broj testiranih, taj procenat u 2014. iznosi $1 \%$.

Antidoping agencija Republike Srbije je realizovala i nekoliko međunarodnih projekata $\mathrm{i}$ istraživanja: projekat sa WADA - „Medical Doctors and Doping in Sport: Attitudes and Experience in Balkan Region - 8 Countries Study, projekte sa FIBA - „The use of medication and nutritional supplements during FIBA EuroLeague Women 2009 and EuroCup / EuroChallenge Men 2009“ $\mathrm{i}$ „Hydration assessment of basketball teams - participants of U20 European Championship Men 2011 - Division B“, kao i projekat sa UNESCO - „New curriculum of anti-doping education in Serbia“.

Značajna je i aktivnost ADAS u procesu suplementacije naših vrhunskih sportista i olimpijskih kandidata, koja se sprovodi u saradnji sa Olimpijskim komitetom Srbije, nacionalnim sportskim savezima i sa Centrom za sportsku ishranu i suplementaciju. Značajan je projekat testiranja dijetetskih suplemenata na eventualnu kontaminiranost anaboličkim steroidima i stimulansima u Kelnskoj laboratoriji, kao i obeležavanja testiranih suplemenata markicama „DOPING FREE”.

Kada se, međutim, govori o stručnom radu, verovatno je podjednako važan i rad na izuzeće za terapeutsku upotrebu (TUE) koje važi za sve supstance ili metode koje se nalaze na Listi zabranjenih doping sredstava, a koje sportista mora da uzima zbog određenog stanja ili bolesti.

Sportisti se može odobriti korišćenje zabranjenih supstanci i/ili metoda koje se nalaze na Listi zabranjenih doping sredstava u terapijske svrhe u slučaju kada za to postoji jasna i nužna medicinska indikacija.

Korišćenje zabranjenih supstanci i/ili metoda u terapijske svrhe odobrava se isključivo ako sportista može da dokaže da je zadovoljen svaki od sledećih kriterijuma:
- neuzimanje zabranjenih supstanci ili metoda značajno bi pogoršalo njegovo zdravlje

- terapijsko korišćenje zabranjenih doping supstanci i/ ili metoda neće izazvati nikakvo dodatno poboljšanje sportskih sposobnosti;

- ne postoji adekvatna terapijska alternativa zabranjenoj doping supstanci i/ili metodi;

- neophodnost korišćenja zabranjenih doping supstanci i/ili metoda nije posledica njihovog prethodnog neterapeutskog korišćenja.

Pet sportova (od ukupno 26 različitih) koji su imali najveći broj prijava TUE od 2007. godine su: košarka, fudbal, veslanje, rvanje i vaterpolo. Razlog za ovakvu raspodelu nalazi se, pre svega, $u$ masovnosti određenih sportova $u$ Srbiji, ali i u nivou takmičenja na koje ovi sportisti odlaze. Učestvovanje na svetskim i međunarodnim takmičenjima podrazumeva i strogo poštovanje pravila koja se tiču prijave TUE.

Najzastupljenije dijagnoze zbog kojih su sportisti morali da prijave TUE bile su iz grupe inflamatornih stanja lokomotornog aparata: entezitisi, tendinitisi i fasciitisi (17\%). Astma i lumbalni sindrom se nalaze na drugom i trećem mestu po broju prijava TUE sa $14 \%$ i $11 \%$ učestalosti.

Da bi pomogli sportistima, stručnjaci ADAS su im omogućili da pitaju za mišljenje o određenom leku ili suplementu preko zvaničnog portala agencije. Time je napravljen značajan korak u savetovanju sportista, na čemu su izuzetno zahvalni.

Kao primer toga šta sportisti misle o antidoping borbi i radu ADAS možemo navesti činjenicu da je $94 \%$ od ukupno 500 anketiranih učesnika Beogradskog maratona 2014. godine potvrdilo da podržava rad Agencije. S druge strane, rad ADAS ocenjen je od strane Svetske antidoping agencije (WADA) maksimalnom ocenom, kako u pogledu usklađenosti antidoping pravila sa međunarodnim konvencijama, tako i u pogledu rada i sprovođenja pravila. 
U najveće poduhvate i uspehe svakako spada više stotina urađenih kontrola na Evropskom festivalu mladih 2007. godine i Univerzijadi Beograd 2009. godine, četiri godine ekskluzivnih kontrola na FIBA takmičenjima širom Evrope, kao i činjenica da su kontrolori ADAS bili angažovani za doping kontrole na Olimpijskim igrama u Vankuveru, Londonu, Evropskom prvenstvu u fudbalu 2012. u Poljskoj i Ukrajini i Euro Basketu u Poljskoj, Litvaniji, Sloveniji i Francuskoj, kao i da se spremaju za Olimpijske igre u Rio de Žaneiru.

Antidoping agencija Republike Srbije u svojim redovima, između ostalog, ima i 4 licencirana UEFA doping kontrolora, 3 licencirana doping kontrolora Međunarodne asocijacije planinarskih saveza (UIAA) i 2 FIBA nadzorna doktora. Osnivač ADAS, dr Nenad Dikić, potpredsednik je Medicinske komisije FIBA Evrope, predsednik Antidoping komisije UIAA i predsednik TUE komisije Međunarodne federacije za skijanje na vodi (IWSF). Stručni saradnik za izuzeće za terapijsku upotrebu i direktor Centra za sportsku ishranu i suplementaciju, dr Marija Anđelković, osim što je UEFA doping kontrolor i FIBA nadzorni doktor, delegat je i Evropske atletske federacije. Dr Milica Vukašinović Vesić, direktor ADAS, član je Medicinske komisije Evropske plivačke asocijacije (LEN) od maja 2016. godine. Time je na najbolji način demonstrirana ideja da je samo maksimalnim zalaganjem i prisustvom u međunarodnim organizacijama moguće unaprediti naš sport i medicinu.

Antidoping agencija Republike Srbije ima još jednu posebnost, a to je da i pored toga što je državna institucija, sistematizacijom radnih mesta ima i administratora sistema, što je uslovljeno potrebom za obavljanjem sledećih poslova:

- projektovanja i održavanja internet stranice (uglavnom za edukovanje sportista, novosti, itd.);

- onlajn edukacije preko Mudl (engl. Moodle) platforme;

- korišćenja Fejsbuk (engl. Facebook) servisa za obrazovanje i komunikaciju;

- korišćenja Jutjub (engl. Youtube) i Gugl knjige (engl. Google books) servisa za dodatnu edukaciju i komunikaciju;

- razvoja android aplikacija;

- pripreme za štampu svih edukativnih materijala, uključujući i knjige.

Najvažnija je, svakako, internet stranica čija je četvrta verzija urađena u WordPress sa mejling listom kako bismo omogućili svima koji su zainteresovani za temu antidopinga da budu informisani. Pored toga, uveli smo dva veoma popularna servisa - zahtev za mišljenje o suplementu/leku (4).

Internet stranica ADAS beleži oko 97000 poseta i više od 163000 pregleda pojedinačnih stranica od septembra
2008. godine, od kada smo počeli prikupljanje statističkih podataka. Tokom ovog perioda saobraćaj je eksponencijalno rastao, tako da je samo u poslednjih 12 meseci bilo oko 30000 poseta (skoro trećina ukupnog broja poseta), od čega je oko 6\% dolazilo sa Fejsbuka.

Nedavno objavljena vest (5) ima više od 2200 pregleda. Stranica "Osnovna antidoping edukacija”, dobila je oko 7000 pregleda (6). Stranica „Zahtev za mišljenje o suplementu" broji oko 5000 pregleda.

Pored sajta koristimo Mudl platformu za učenje, dizajniranu kao bezbedan i integrisan sistem koji predstavlja personalizovano okruženje za učenje. Pošto veliki broj sportista često nije u stanju da prisustvuje obaveznim predavanjima zbog planiranih treninga i takmičenja, ADAS koristi Mudl platformu (7). Kroz naše Mudl kurseve do sada je prošlo više od 3.000 sportista.

Zbog ogromne popularnosti društvenih mreža, odlučili smo da se uključimo u ovaj vid komunikacije sa sportistima i drugim zainteresovanim stranama kako bismo efikasnije proširili našu edukaciju.

Naša Fejsbuk stranica (8) ima oko 700 članova. Povezana Fejsbuk stranica Udruženja za medicinu sporta Srbije (9) ima oko 500 članova. Ranije pomenuti članak o meldonijumu je pogledalo više od 3000 ljudi na Fejsbuku.

Pored toga, svi naši obrazovni filmovi nalaze se na Jutjubu (10). Naš nedavno postavljen edukativni film „Procedura doping kontrole” (11) imao je oko 60000 pregleda. $\mathrm{Na}$ našem sajtu nalazi se ukupno oko 200 video snimaka postavljenih na Jutjub.

Antidoping agencija Republike Srbije i Udruženje za medicinu sporta Srbije postavili su sve svoje objavljene knjige na Gugl knjige sa besplatnim pristupom, tako da je ceo tekst javno dostupan na internetu. Na Gugl knjige su postavljena i većina predavanja koja smo držali na raznim seminarima. Sve u svemu, tu je oko 90 naslova (12). Među najpopularnijim naslovima su: „Praktična sportska ishrana” (više od 22000 pregleda), „Priručnik za klupske lekare” (oko 17000 pregleda), „Sportsko-medicinski pregled” (oko 12000 pregleda)...

U duhu kontinuirane edukacije sportista bilo je prirodno da proširimo svoje edukativne aktivnosti na sledeću logičnu platformu sa ciljem približavanja sportistima aplikaciju za pametni telefon sa sledećim sadržajem (13):

- listom zabranjenih doping sredstava (LZS): naša aplikacija nudi pretraživu Listu zabranjenih doping sredstava tako da sportista može brzo da proveri da li neki aktivni sastojak, prisutan u leku/dijetetskom suplementu, predstavlja doping;

- izuzećem za terapeutsku upotrebu: ova opcija nudi detaljan tekst na temu izuzeća za terapeutsku upotrebu; 
- mišljenjem o dijetetskom suplementu/leku: ovo će verovatno biti najpopularnija opcija jer nudi pretraživ spisak izdatih mišljenja o raznim lekovima i dijetetskim suplementima;

- ADAMS: sveobuhvatna baza podataka koju održava Svetska antidoping agencija, a koju sportisti koriste da unose podatke o svom kretanju, tako da stalno mogu da budu na raspolaganju za antidoping kontrolu.

- Vesti: aplikacija prikazuje objavljene članke na našem veb sajtu na jednostavan način.

Na kraju se umesto zaključka može reći da, zahvaljujući postojanju Antidoping agencije Republike Srbije, naša zemlja ima:

- uglednu organizaciju sa specifičnim znanjem koje ne pružaju ni ustanove iz oblasti sporta ni ustanove iz oblasti zdravstva i sportske medicine. Iza stručnjaka ADAS stoje deset godina međunarodne edukacije i usavršavanja, poznavanje sistema antidopinga i uspostavljanje organizacije antidoping borbe u Srbiji, a iza doping kontrolora ADAS stoje veliko međunarodno iskustvo, stručnost i znanje;

- broj sportista pozitivnih na doping na nivou svetskog proseka. Do 2011. godine procenat pozitivnih u Srbiji kretao se oko 4\%. Od 2011. godine ovaj procenat se smanjio na nivo od 1,5 do $2 \%$, čime smo se izjednačili sa svetskim prosekom od 1-2\%;

- zapaženu međunarodnu poziciju (zahvaljujući dobrom radu ADAS Srbija je 2 godine imala predstavnika u Osnivačkom odboru WADA koji broji 18 članova predstavnika država i 18 članova predstavnika Olimpijskog pokreta; ADAS je angažovan za doping kontrole na preko 50 međunarodnih takmičenja, uključujući i kontrole $\mathrm{u}$ inostranstvu; kontrolori ADAS su angažovani na tri Olimpijade do sada, evropskim prvenstvima u fudbalu, košarci i slično);

- telo koje veštači u sudskim sporovima koji uključuju krivična dela vezana za distribuciju doping supstanci. U Srbiji su predviđena 2 krivična dela vezana za distribuciju, davanje ili upotrebu doping supstanci, za koja su predviđene višegodišnje zatvorske kazne, kao i niz prekršajnih dela. Predstavnici ADAS su do sada veštačili, tj. davali stručna mišljenja u 5 krivičnih postupaka pred tri različita Viša suda u Srbiji i učestvovali u prekršajnim postupcima;

- lidersko mesto u regionu na polju antidoping borbe;

- pre svega edukativnu ustanovu jer je obrazovanje prepoznato kao ključni razlog za smanjenje broja slučajeva pozitivnih na doping u Srbiji tokom deset godina rada ove institucije.

\section{Literatura}

1. Dikic N, McNamee M, Günter H, Markovic SS, Vajgic B. Sports physicians, ethics and antidoping governance: between assistance and negligence. Br J Sports Med. 2013;47(11):701-4.

2. Dikic N, Samardzic Markovic S, McNamee M. On the Efficacy of WADAs Whereabouts Policy: Between Filing Failures and Missed Tests. Deutsche zeitschrift fur sportmedizin. (2011), vol. 62 (10): 324

3. Vukasinovic-Vesic Milica, Andjelkovic Marija, Stojmenovic Tamara, Dikic Nenad, Kostic Marija, Curcic Djordje, Sweat rate and fluid intake in young elite basketball players on FIBA Europe U20 Championship, Vojnosanit Pregl 2015; 72(12): 1063-1068.

4. http://www.adas.org.rs

5. http://www.adas.org.rs/vesti/2016/03/08/zasto-je-lek-mildronat-meldonium-zabranjen-u-sportu/
6. http://www.adas.org.rs/en/vesti/2016/02/26/adas-pokrenuo-program-vrsnjacke-edukacije-o-borbi-protiv-dopinga

7. http://online-kurs.cis.edu.rs

8. https://www.facebook.com/ADAS.Srbija

9. https://www.facebook.com/MedicinaSporta

10. http://www.adas.org.rs/youtube-kanal-adas

11. https://www.youtube.com/watch?v=zCOsX1CJVps

12. http://smas.org/izdavacka-delatnost.html

13. http://www.adas.org.rs/edukacija/android-aplikacija-adas-za-sportiste 